\title{
25 Research Soure \\ Electrocoagulation Applied for Textile Dye Oxidation Using Iron Slag as Electrodes
}

Rafaela De Maman

UFFS: Universidade Federal da Fronteira Sul

Vilson Conrado da Luz

UFFS: Universidade Federal da Fronteira Sul

Laura Behling

UFFS: Universidade Federal da Fronteira Sul

Adriana Dervanoski

UFFS: Universidade Federal da Fronteira Sul

Clarissa Dalla Rosa

UFFS: Universidade Federal da Fronteira Sul

Gean Delise Leal Pasquali ( $\sim$ geandelise@uffs.edu.br)

Universidade Federal da Fronteira Sul https://orcid.org/0000-0001-5110-6532

\section{Research Article}

Keywords: Electrochemistry, Textile effluent, Foundry industry waste, Wastewater, Dyes, Textile industry

Posted Date: May 28th, 2021

DOI: https://doi.org/10.21203/rs.3.rs-477015/v1

License: (c) (i) This work is licensed under a Creative Commons Attribution 4.0 International License.

Read Full License 


\section{Abstract}

The Indigo Blue dye is widely used in the textile industry, specifically in jeans dyeing, the effluents of which, rich in organic pollutants with recalcitrant characteristics, end up causing several environmental impacts, requiring efficient treatments. Several pieces of research have been conducted in search of effective treatment methods, among which is electrocoagulation. This treatment consists of an electrochemical process that generates its own coagulant by applying electric current on metallic electrodes, bypassing the use of other chemical products. The objective of this work was to evaluate the potential use of iron slag in the electrocoagulation of a synthetic effluent containing commercial dye Indigo Blue and the effluent from a textile factory. The quantified parameters were color, turbidity, $\mathrm{pH}$, electrical conductivity, sludge generation, phenol removal, chemical oxygen demand (COD), and total organic carbon (TOC). The electrocoagulation treatment presented a good efficiency in removing the analyzed parameters, obtaining average removal in the synthetic effluent of $85 \%$ of color and $100 \%$ of phenol after $25 \mathrm{~min}$ of electrolysis. For the effluent from the textile factory, average reductions of $80 \%$ of color, $91 \%$ of turbidity, $100 \%$ of phenol, $55 \%$ of COD, and $73 \%$ of TOC were measured after 60 min of electrolysis. The results obtained demonstrate the potential of using iron slag as an electrode in the electrocoagulation process in order to reuse industrial waste and reduce costs in the treatment and disposal of solid waste.

\section{Introduction}

The textile industry stands out as one of the most polluting sectors in terms of the volume and complexity of the effluents produced. The dyeing and finishing processes contribute significantly to the generation of wastewater through the use of dyes during the production process, promoting an effluent with specific characteristics, such as intense color, high chemical oxygen demand (COD), a large amount of dissolved solids, and pH variation (Zaroual et al., 2006; Cerqueira et al., 2009; Mook et al., 2017).

Due to the presence of dyes, several environmental impacts may be caused when this effluent is discharged without meeting the regulatory requirements. One of these impacts occurs by partially reducing the penetration of sunlight into the aquatic environment, hindering the photosynthesis process and the production of oxygen by aquatic plants, thus directly affecting the amount of dissolved oxygen present in the environment, causing serious effects on the life cycle of fish (Chakraborty, 2014). Also, high concentrations of nitrogen, phenols, iron, and chromium, which end up harming aquatic life, and high COD and biochemical oxygen demand (BOD) values may result in the reduction of oxygen in the affected ecosystem (Chakraborty, 2014; Buscio et al., 2015; Liu et al., 2019).

Indigo Blue dye is widely used in the coloring of jeans (Abdelileh et al. 2020). The structural and chemical properties of indigo blue make it poorly soluble in water (Volkov et al., 2020; Yin et al., 2020). Thus, the fiber dyeing process occurs through a series of oxidation-reduction processes: immersion in a sodium dithionite bath entails the reduction of the dye, which takes the leuco-indigo form, presenting high solubility in water and affinity with the fiber for dyeing; after immersion, the fiber is exposed to air to 
return to the original insoluble form (Albuquerque et al., 2013; Abdelileh et al., 2020; Hendaoui et al., 2021).

There are numerous physicochemical, chemical, and biological techniques for the treatment of these textile effluents. Due to the environmental implications, in addition to conventional treatments, research has emerged using new treatment technologies for the degradation of these compounds, among which electrochemical processes have stood out (Holkar et al., 2016; Bener et al., 2019).

Electrocoagulation is a widely applied technique for pollutant removal widely used in the treatment of textile effluents due to its environmental friendliness, versatility, energy efficiency, safety, and costeffectiveness. It uses simple equipment of easy operation, which facilitates its maintenance (Khandegar and Soroha, 2013). The electrochemical reactor is composed of an electrolyte and two electrodes (cathode and anode). Oxidation-reduction reactions occur at the electrodes through the application of a continuous electric current, and a coagulant is released into the effluent by the anode through the oxidation of the material. At the cathode, the electrode reduction process occurs, releasing hydroxyl ions to the medium (Gendel and Lahav, 2010). After this combination of reactions, water electrolysis occurs, producing oxygen at the anode and hydrogen at the cathode, forming microbubbles and causing the flocculation of the particles present in the effluent (Mollah et al., 2004; Verma, 2017).

The most commonly used materials in electrochemical treatments are aluminum and iron; however, other materials have been used as electrodes in various studies, such as zinc, stainless steel, galvanized steel, steel, graphite, platinum, and diamond (Lee and Gagnon, 2015; Silva et al., 2016; Zazou et al., 2019), and industrial waste such as scrap metal may also be used. The foundry industry in Brazil in the first half of 2018 was responsible for producing approximately 800,000 tons of castings, of which 600,000 tons represent the production of cast iron, a volume $6 \%$ higher than in 2017 (Carmelio et al., 2018). In the process of casting metal parts, a solid residue called slag is produced. This residue is rich in iron and, because it has no other application, ends up in industrial landfills.

Aiming at the sustainability of the environment and cost reduction for the industry through using the waste generated and reducing landfill disposal, the present work shows the evaluation of the application of iron slag from a foundry as electrodes in an electrochemical process employed as a secondary treatment for color removal in synthetic and real effluents containing textile dye.

\section{Materials And Methods}

\subsection{Electrodes}

The iron slag was obtained at a foundry located in Erechim, RS, Brazil. The collected raw material needed to be broken manually for obtaining smaller parts to be used as electrodes (Fig. 1). After breaking, the raw scoria pieces were weighed, and cathode and anode pairs with similar masses were formed. The characterization of the raw iron slag has already been reported in previous work by Bragagnolo et al. (2018), and the main constituents of the material are presented in Table 1. 


\section{Table 1}

Properties and constituents of the raw iron slag used as electrodes for textile dye oxidation

\begin{tabular}{|c|c|c|c|c|}
\hline \multicolumn{3}{|c|}{ Constituents } & \multirow{2}{*}{$\begin{array}{l}\text { Properties } \\
\text { Loss on ignition (\%) }\end{array}$} & \multirow{2}{*}{$\begin{array}{l}\text { Reference } \\
\text { Bragagnolo et al. (2018) }\end{array}$} \\
\hline Oxides & $(\%)$ & Others (\%) & & \\
\hline $\mathrm{SiO}_{2}$ & 70.4 & 2.38 & 1.32 & \\
\hline $\mathrm{AlO}_{3}$ & 13.6 & - & - & \\
\hline $\mathrm{K}_{2} \mathrm{O}$ & 4.98 & - & - & \\
\hline $\mathrm{Fe}_{2} \mathrm{O}_{3}$ & 3.29 & - & - & \\
\hline $\mathrm{Na}_{2} \mathrm{O}$ & 2.79 & - & - & \\
\hline $\mathrm{CaO}$ & 1.20 & - & - & \\
\hline
\end{tabular}

\subsection{Electrochemical reactor}

The reactor used for the treatment was made of glass with the dimensions $15 \mathrm{~cm} \times 30 \mathrm{~cm}$, totalizing a volume of $3 \mathrm{~L}$ of effluent per treatment (Fig. 2). The wires used were of a $6 \mathrm{~mm}$ gauge, stripped $10 \mathrm{~cm}$ at one end to wrap the slag and $5 \mathrm{~cm}$ at the other end to connect to the power source, being changed at each experiment. The electric current applied in the treatments was based on the literature, ranging from $0.3 \mathrm{~A}$ to $0.9 \mathrm{~A}$ (Ghanbari et al., 2014; Matias et al., 2015). For better electron conductivity in the effluent, 1 $\mathrm{g} \mathrm{L}^{-1}$ of $\mathrm{NaCl}$ was added to each treatment. All trials were performed at room temperature of $20^{\circ} \mathrm{C}$ to 25 ${ }^{\circ} \mathrm{C}\left( \pm 1.0^{\circ} \mathrm{C}\right)$, and unadjusted $\mathrm{pH}$ from 7.5 to $8.7( \pm 1.2)$ was used.

\subsection{Synthetic effluent}

The synthetic effluent consisted of commercial Indigo Blue dye, requiring grinding and sieving before use in order to achieve its homogenization. The concentration limits used were based on the literature, ranging from $50 \mathrm{mg} \mathrm{L}^{-1}$ to $80 \mathrm{mg} \mathrm{L}^{-1}$ (Ghalwa et al., 2016; Hendaoui et al., 2021).

The electrolysis time in the synthetic effluent treatment was set at 25 min after analyzing the color removal kinetics performed (Fig. S1) using the dye concentration of $32.2 \mathrm{mg} \mathrm{L}^{-1}$ and removing samples every $10 \mathrm{~min}$ of the treatment until the color removal stabilized.

The experiments were performed following a $2^{2}$ factorial experiment design (Table 2), analyzing the variables of electric current $(0.3 \mathrm{~A}$ to $0.9 \mathrm{~A})$ and dye concentration $\left(50 \mathrm{mg} \mathrm{L}^{-1}\right.$ to $\left.80 \mathrm{mg} \mathrm{L}^{-1}\right)$. The combination of these variables using experimental planning resulted in a total of eleven trials, as shown in Table 3. 


\section{Table 2}

Levels and variables used in the experimental design of the electrocoagulation process for the oxidation of textile dye from synthetic effluent.

Variables

Level

$a=-1.41 \quad-1 \quad 0 \quad+1 \quad a=+1.41$

Current $(A)$

0.3

0.45

0.6

0.75

0.9

Dye Concentration $\left(\mathrm{mg} \mathrm{L}^{-1}\right)$

50

58

65

73

80

Table 3

Matrix of the $2^{2}$ factorial experiment design with coded values for the electrocoagulation process for the oxidation of textile dye from synthetic effluent.

\begin{tabular}{|lll|}
\hline Exp. run No. & Current & Dye concentration \\
\hline 1 & -1 & +1 \\
\hline 2 & -1 & -1 \\
\hline 3 & +1 & +1 \\
\hline 4 & +1 & -1 \\
\hline 5 & 0 & 0 \\
\hline 6 & 0 & 0 \\
\hline 7 & 0 & 0 \\
\hline 8 & -1.41 & 0 \\
\hline 9 & +1.41 & 0 \\
\hline 10 & 0 & -1.41 \\
\hline 11 & 0 & +1.41 \\
\hline
\end{tabular}

\subsection{Real textile effluent}

The industrial textile effluent was obtained from a Jeans company located in Erechim, RS, Brazil. It was collected in an equalization tank after a sieve system. The experiments using the real effluent totalized fifteen runs, and only the electric current was analyzed as a variable since the initial color concentration was determined in the effluent characterization stage. Thus, each current used in the real effluent ( $0.3 \mathrm{~A}$ to 0.9 A) was analyzed in triplicate to understand the influence of the electric current on the electrochemical 
treatment. The electrolysis time was set at $1 \mathrm{~h}$; after analyzing the color removal kinetics using the actual effluent, samples were collected every 10 min until the color removal stabilized (Fig. S2).

\subsection{Analytical Methodology}

The electric current applied to the treatments was based on the literature, ranging from $0.3 \mathrm{~A}$ to $0.9 \mathrm{~A}$ (Ghanbari et al., 2014; Matias et al., 2015). For better electron conductivity in the effluent, $1 \mathrm{~g} \mathrm{~L}^{-1}$ of NaCl was added to each treatment. All assays were performed at room temperature $\left(20^{\circ} \mathrm{C}\right.$ to $\left.25^{\circ} \mathrm{C}\right)$, and unadjusted $\mathrm{pH}$ was used in the range of 7.5 to 8.7. At the end of each run, the initial and final treatment samples were analyzed for Color (method 2120 B), Turbidity (method 2130 B), pH, conductivity, Phenol (method 5530 D), Chemical Oxygen Demand (method 5220 D), and Total Organic Carbon (method 5310 B), with all parameters being evaluated according to the methodology proposed by the Standard Methods for the Examination of Water and Wastewater (APHA, 2005). The pieces of equipment used in this study are available in the electronic supplementary material 1 (Text S1). In addition to these parameters, sludge production and electrode wear were also analyzed using the Gravimetric Method. The statistical analysis was performed using software Minitab 15, and graphs were made using GraphPad Prism 8.

\section{Results And Discussion}

\subsection{Electrocoagulation of the synthetic textile effluent}

The results of applying the electrocoagulation process with iron slag electrodes to the synthetic effluent are presented in Table 4, showing the values of the initial and final concentrations for color removal, according to the experimental design. One may observe an efficient color removal in the effluent, varying from $68 \%$ to $95 \%$, presenting a removal average of $85 \%$. This variation in color removal may occur due to the composition of the iron slag electrodes because the concentrations of iron and other constituents of the electrodes are not known with accuracy since they are made of solid foundry residues and replaced at each new treatment; therefore, there may be variability in their composition. 
Table 4

Color removal from synthetic wastewater containing textile dye by the electrocoagulation process using iron slag electrodes.

\begin{tabular}{|llll|}
\hline Exp. run No. & Initial concentration $\left(\mathrm{mg} \mathrm{L}^{-1}\right)$ & Final concentration $\left(\mathrm{mg} \mathrm{L}^{-1}\right)$ & Color removal (\%) \\
\hline 1 & 91.4 & 23.85 & 73.90 \\
\hline 2 & 76.51 & 5.08 & 93.35 \\
\hline 3 & 97.12 & 10.38 & 89.30 \\
\hline 4 & 69.77 & 3.04 & 95.64 \\
\hline 5 & 69.77 & $15.49^{*}$ & 77.80 \\
\hline 6 & $4.06^{*}$ & 93.89 \\
\hline 8 & 67.51 & $4.67 *$ & 93.05 \\
\hline 9 & 71.40 & 22.83 & 68.01 \\
\hline 10 & 69.16 & 4.46 & 93.53 \\
\hline 11 & 46.30 & 14.46 & 68.75 \\
\hline$*$ & 10.18 & 90.30 \\
\hline
\end{tabular}

In the present study, the color removal efficiency using the proposed treatment was verified. Even with the complex composition of the iron slag electrodes, a high color removal efficiency reaching $95 \%$ was obtained. In work developed by Verma (2017), electrocoagulation was applied to a synthetic effluent containing $200 \mathrm{mg} \mathrm{L}^{-1}$ of dye using one iron and one aluminum electrode, resulting in $86 \%$ color removal after $1 \mathrm{~h}$ of treatment.

One of the main parameters for the efficiency of the electrocoagulation treatment is the amount of coagulant generated, which is related to the applied electric current density and the electrolysis time (Kabdasli et al., 2010). According to studies by Azarian et al. (2018) and Nariyan et al. (2017), the pollutant removal efficiency of an electrocoagulation treatment is directly proportional to the applied electric current density, explained by Faraday's Law. However, after a statistical analysis of the experimental results obtained in this study, it was observed that the two variables analyzed (i.e., electric current intensity and dye concentration) did not show significant effects on the efficiency of color removal from the synthetic effluent. This statement may be confirmed through the Pareto chart with $95 \%$ confidence (Fig. 3).

The $\mathrm{pH}$ and electrical conductivity values obtained in the eleven tests performed are shown in Fig. 4a. One may observe that the $\mathrm{pH}$ values after the electrocoagulation treatment are above the value allowed for discharging liquid effluents into water bodies ( $\mathrm{pH}$ between 5 and 9) according to Resolution No. 430 of the Brazilian National Environment Council (CONAMA) (Conama, 2011). 
In electrochemical processes, the $\mathrm{pH}$ increases during the treatment due to the generation of $\mathrm{OH}^{-}$ions during the water reduction step (Cerqueira et al., 2009). In electrocoagulation, the final pH is high compared to the initial $\mathrm{pH}$, corroborating the values obtained in this study. Cerqueira et al. (2009) evaluated the initial $\mathrm{pH}$ as an influencing parameter in electrocoagulation using iron electrodes and observed that the initial $\mathrm{pH}$ of 7 led to better values of color and turbidity removal and COD. Ramazan et al. (2019) studied the effect of $\mathrm{pH}$ applying different electrolytes using iron electrodes, reporting that, by adding $\mathrm{NaCl}$ to the solution to be treated, the $\mathrm{pH}$ increased from 7.2 to 11.35.

Brazilian regulations do not establish guideline values of electrical conductivity (Fig. 4b) for discarding effluents into water bodies. Bande et al. (2008) observed that introducing a higher concentration of $\mathrm{NaCl}$ into the effluent to be treated results in an increase in conductivity and a decrease in the voltage offered by the effluent, thus reducing the amount of energy required to perform the electrocoagulation process. However, Wang et al. (2009) showed that a large increase in the $\mathrm{NaCl}$ concentration should not occur as it affects the COD reduction efficiency, with an excess of $\mathrm{Cl}^{-}$ions in the medium being unfavorable to the coagulation of pollutants.

The wear of the iron slag electrodes (Fig. 5) was determined by weighing them before and after the treatment. For there not to occur mass loss with the washing of the electrodes, the use of abrasive materials was avoided and, after each test, the electrodes only received distilled water to remove the generated sludge that could have adhered to the iron slag for subsequent weighing and disposal.

In the study by Zazouli and Taghavi (2012), the wear of the electrodes was remarkable at higher current densities. In this study using iron slag, the current density showed no effect on the electrode wear; however, it should be taken into account that the maximum limit of the current applied in this study was 9 A, unlike the maximum current of $25 \mathrm{~A}$ applied by Zazouli and Taghavi (2012).

The sludge production in the electrocoagulation process using iron slag electrodes in a synthetic effluent is represented in Fig. 6. One may observe the increase in sludge generated as the intensity of the electric current is raised; this behavior was expected since there is a direct relationship between the amount of sludge formed and the current applied in the electrochemical process. Studies by Zodi et al. (2009) and Chen (2004) confirm the increase observed in this study. The authors reported that, when using iron and aluminum electrodes in electrocoagulation, they obtained results where the sludge formation is directly related to the density of the current applied. The amount of sludge formed is also related to the volume of coagulant material produced with the removal of total suspended solids and other compounds present in the effluent.

A small phenol presence was observed with an initial concentration ranging from $0.3 \mathrm{mg} \mathrm{L}^{-1}$ to $9.1 \mathrm{mg}$ $\mathrm{L}^{-1}$; these concentrations were $100 \%$ removed. Despite the complexity of the composition of the iron slag used, the removal was very efficient for this type of pollutant. The study conducted by Silva et al. (2016) corroborates the results obtained in this study: the authors evaluated the removal of contaminants 
in a textile effluent through electrochemical degradation, obtaining approximately $100 \%$ of phenol removal.

The TOC concentration was also evaluated initially and at the end of the trials. In the treatment, there occurred a TOC removal of approximately $18 \%$. The other assays did not present TOC removal. The initial TOC concentrations found ranged from $6 \mathrm{mg} \mathrm{L}^{-1}$ to $14 \mathrm{mg} \mathrm{L}^{-1}$. For evaluating this parameter, it is necessary to consider the chromophore group breakdown; such chemical groups are responsible for the coloration of the dye, being the structure responsible for its fixation to the textile fiber (Paschoal and Temiliosi-Filho, 2005). The results obtained in the TOC analyses suggest that the electrocoagulation process may only be breaking this chromophore group bond and, therefore, only removing the color and not the organic matter present in the effluent considering the low TOC removal obtained.

\subsection{Electrocoagulation in a real industrial textile effluent}

The effluent collected from the textile industry was characterized in order to know its properties (Table 5).

Table 5

Characterization of the raw textile effluent collected in an equalization tank after a screening system.

\begin{tabular}{|ll|}
\hline \multicolumn{2}{|l|}{ Characterization of the raw effluent } \\
\hline Color & $887.7 \mathrm{Pt} \mathrm{Co} \mathrm{L}^{-1}$ \\
\hline Turbidity & $1042.60 \mathrm{NTU}$ \\
$\mathrm{pH}$ & 8.06 \\
\hline Conductivity & $673.7 \mu \mathrm{S} \mathrm{cm}^{-1}$ \\
\hline Temperature & $22^{\circ} \mathrm{C}$ \\
\hline COD & $664.0 \mathrm{mg} \mathrm{O}_{2} \mathrm{~L}^{-1}$ \\
\hline BOD & $1076.2 \mathrm{mg} \mathrm{O}_{2} \mathrm{~L}^{-1}$ \\
\hline Total Solids & $68.40 \mathrm{mg} \mathrm{L}^{-1}$ \\
\hline Phenol & $1.17 \mathrm{mg} \mathrm{L}^{-1}$ \\
\hline TOC & $208.20 \mathrm{mg} \mathrm{L}^{-1}$ \\
\hline
\end{tabular}

Through the application of the electrocoagulation process using iron slag electrodes in the industrial effluent, it was possible to observe the reduction of color, turbidity, TOC, and COD under each current applied. Figure 7 presents the mean values of the removals in triplicate.

The best results obtained for the removal of color and turbidity were observed with the smallest electric current applied (0.3 A): $80 \%$ of color and $91 \%$ of turbidity were removed. These values show that the 
applied electric current did not present significance in the electrocoagulation treatment under the evaluated conditions, with it being possible to use low electric currents and obtain high treatment efficiencies, saving costs with applied electric energy.

According to the CONAMA resolution No. 430, which provides for the liquid effluent discharge standards (Conama, 2011), the color parameter has no concentration limit, with the only condition being that it should not change the color of the water body. Thus, CONAMA resolution No. 357, which provides for the classification of water bodies and effluent discharge standards (Conama 2005), was used as a reference for discharge. For Brazilian Class I rivers, the natural true color of the water body is required, while for Class II the true color has a limit of $75 \mathrm{mg} \mathrm{Pt} \mathrm{L}^{-1}$. The final concentration values after the electrocoagulation treatment are all below the limit allowed for Class II rivers, which would allow the release of the treated effluent into the water body without the need for secondary treatment.

Núñez et al. (2019) evaluated the application of electrocoagulation for removing color and turbidity from textile factory wastewater using iron electrodes. The authors used $200 \mathrm{~mL}$ of the industrial effluent and an electrolysis time of 10 min, finding removal efficiencies of $70 \%$ for color and $45 \%$ for turbidity, values lower than for the treatment applying iron slag as electrodes in this study.

In the evaluation of the reduction in TOC, the values were close for each current applied, not demonstrating a significant variation, finding with the current of $0.9 \mathrm{~A}$ an efficiency of $73 \%$. For the COD, a maximum reduction of $55 \%$ was obtained with the application of a current of $0.6 \mathrm{~A}$; the other current intensities led to average reductions of $30 \%$. Phenol removal was also evaluated, and the treatment presented an efficiency of $100 \%$, with total removal occurring in all the tests.

Sirma et al. (2019) evaluated TOC and COD reduction in a textile effluent by the electrocoagulation process using $800 \mathrm{~mL}$ of the effluent and aluminum and iron electrodes. The authors reported better removals of TOC for the aluminum electrode $(29 \%)$, while the iron electrode only achieved a $5 \%$ removal. As for the COD reduction, the authors found a low efficiency, with a maximum reduction of $19 \%$. These values show that iron slag is efficient in reducing TOC and COD, presenting reductions in the order of 73 $\%$ and $55 \%$, respectively.

The sludge production in the electrocoagulation process using iron slag electrodes in industrial effluents showed values directly related to the increase in electric current (Fig. 8).

A large standard deviation of the sludge production is noticeable. This is attributed to the intrinsic characteristics of iron slag since it is a solid waste of varied composition, making it difficult to predict sludge production. However, even with the high deviation observed, the amount of sludge generated is reduced, which would justify its application in the process.

When applying a high current density in the treatment, an increase in the anodic metal dissolution is observed and, consequently, an increase in the amount of sludge produced (Zodi et al., 2009). This reaction of increased sludge production is evident in the tests performed using iron slag: the higher the 
electric current density, the greater the amount of sludge produced. When studying the electrocoagulation process for the decolorization of textile wastewater, Bener et al. (2019) showed that the wear of the electrodes is directly related to the applied electric current density. However, when using iron slag, the observed behavior was not similar: the most considerable wear presented was at the intermediate current of $0.6 \mathrm{~A}$ (Fig. 9), possibly due to the characteristics of the slag itself.

\section{Conclusions}

The electrocoagulation process using iron slag as electrodes showed good efficiency in treating a synthetic effluent and an industrial effluent containing textile dye. This process presents a great advantage related to cost reduction due to the non-addition of inputs since it is a residue produced in the foundry industry, besides being environmentally and financially interesting given that its application in effluent treatment would also reduce its disposal in industrial landfills, thus contributing to the foundry industry by reducing the cost of the disposal of this material.

Some points still have to be investigated in order to reach the release standards, such as the $\mathrm{pH}$ that was above the allowed by the Brazilian regulations in both analyzed effluents and the TOC removal, which did not show significant results in the evaluated tests with the synthetic effluent, requiring greater attention to the chromophore group. From the statistical analysis of the data obtained, it is observed that none of the variables evaluated (i.e., electric current and dye concentration) presented statistical significance in the treatment $(p<0.05)$.

The use of iron slag as an electrode was limited because it presents uncertainties in the concentration of iron in each fraction used in the treatment, which leads to varying results for each test performed. However, electrocoagulation is a method that has many strengths, thus requiring a better evaluation of the use of iron slag in the process for understanding its behavior in the electrochemical treatment.

\section{Declarations}

\section{Ethics approval and consent to participate:}

Not applicable

\section{Consent for publication:}

Not applicable

\section{Availability of data and materials:}

All data generated or analysed during this study are included in this published article [and its supplementary information files]. 


\section{Competing interests:}

The authors declare that they have no competing interests

\section{Funding:}

Federal University of Fronteira Sul (UFFS) was responsible for the laboratory area and the acquisition of reagents and equipment; Rio Grande do Sul State Research Support Foundation (FAPERGS) for the financial support (scientific initiation scholarship $n^{\circ} 194$ / UFFS / 2019)

\section{Authors' contributions:}

All authors contributed to the study conception and design. Material preparation, data collection and analysis were performed by Rafaela De Maman, Gean Delise Leal Pasquali, Vilson Conrado da Luz, Laura Behling, Clarissa Dalla Rosa and Adriana Dervanoski. The first draft of the manuscript was written by Rafaela De Maman, Laura Behling, Vilson Conrado da Luz and Gean Delise Leal Pasquali and all authors commented on previous versions of the manuscript. All authors read and approved the final manuscript.

\section{Acknowledgements:}

The authors gratefully acknowledge the Rio Grande do Sul State Research Support Foundation (FAPERGS) for the financial support (grant $n^{\circ} 194 /$ UFFS/2019)

\section{References}

1. Abdelileh M, Manian A, Rhomberg D, Ticha MB, Meksi N, Aguiló-Aguayo N, Bechtold T (2020) Calcium-iron-D-gluconate complexes for the indirect cathodic reduction of indigo in denim dyeing: A greener alternative to non-generable chemicals. Journal of Cleaner Production 121753. https://doi.org/10.1016/j.jclepro.2020.121753

2. Albuquerque LF, Salgueiro AA, Melo JL, Chiavone-Filho O (2013) Coagulation of índigo blue presente in dyeing wastewater using a residual bittern. Separation and Purification Technology 104:246 249. https://doi.org/10.1016/j.seppur.2012.12.005

3. APHA, AWWA, WEF (2005) Standard methods for the examination of water and wastewater. Amer Public Health Assn, Washington

4. Azarian G, Rahmani RA, Masoudi M, Atashzaban Z, Nematollahi D (2018) New batch electrocoagulation process for treatment and recovery of high organic load and low volume egg processing industry wastewater. Process. Saf. Environ. Prot 119:96-103.

https://doi.org/10.1016/j.psep.2018.07.025 
5. Bande RM, Prasad B, Mishra IM, Wesawar KL (2008) The oil effluent water treatment for safe disposal by electroflotation. Chemical Engineering Journal 137:503-509. https://doi.org/10.1016/j.cej.2007.05.003

6. Bener S, Bulca O, Palas B, Tekin G, Atalay S, Ersoz G (2019) Electrocoagulation process for the treatment of real textile wastewater: Effect of operative conditions on the organic carbon removal and kinetic study. Process Safety and Environmental Protection 129:47-54. https://doi.org/10.1016/j.psep.2019.06.010

7. Bragagnolo L, Ferrazzo ST, Muscope FP, Korf EP, Vargas GDLP, Rosa CD, Piazzetta LVH, Tormen FA (2018) Caracterização de resíduos da fundição de ferro e avaliação de possíveis aplicações na construção civil. Revista Brasileira De Ciências Ambientais 50:61 - 77. https://doi.org/10.5327/Z2176-947820180390

8. Buscio V, Marín MJ, Crespi M, Gutiérrez-Bouzán C (2015) Reuse of textile wastewater after homogenization-decantation. Chemical Engineering Journal 265:122-128. https://doi.org/10.1016/j.cej.2014.12.057

9. Carmelio JS et al. (2018) Guia ABIFA de Fundição. Associação Brasileira de Fundição. ABIFA, São Paulo

10. Cerqueira A, Russo C, Marques MRC (2009) Electroflocculation for textile wastewater treatment. Braz. J. Chem. Eng 26:659-668. https://doi.org/10.1590/S0104-66322009000400004.

11. Chakraborty, J. N (2014) Wastewater problems in textile industry. In: Chakraborty JN. Fundamentals and Practices in Colouration of Textiles. Woodhead Publishing India pp. 515-545.

12. Chen G (2004) Electrochemical technologies in wastewater treatment. Sep. Purif. Technol 38:11-41. https://doi.org/10.1016/j.seppur.2003.10.006

13. Conama (2005) Resolução CONAMA n 357/2005. Brasília. http://www2.mma.gov.br/port/conama/legiabre.cfm?codlegi=459. Accessed 27 fev 2020

14. Conama (2011) Resolução CONAMA n 430/2011. Brasília. http://www2.mma.gov.br/port/conama/legiabre.cfm?codlegi=646. Accessed 23 jan 2018

15. Gendel Y, Lahav $O$ (2010) A new approach to increasing the efficiency of low-pH Feelectrocoagulation applications. Journal of Hazardous Materials 183(1-3):596-601. https://doi.org/10.1016/j.jhazmat.2010.07.066

16. Ghalwa NMA, Saqer AM, Farhat NB (2016) Removal of Reactive Red 24 Dye by Clean Electrocoagulation Process Using Iron and Aluminum Electrodes. Journal of Chemical Engineering \& Process Technology Palestine 7:1-7. https://doi.org/10.4172/2157-7048.1000269

17. Ghanbari F, Moradi M, Eslami A, Emamjomeh MM (2014) Electrocoagulation/Flotation of Textile Wastewater with Simultaneous Application of Aluminum and Iron as Anode. Environ. Process. 1:447-457 (2014). https://doi.org/10.1007/s40710-014-0029-3

18. Hendaoui K, Trabelsi-Ayadi M, Ayari F (2021) Optmization and mechanisms analysis of indigo dye removal using continuos electrocoagulation. Chinese Journal of Chamical Engineering 29:242-252. https://doi.org/10.1016/j.cjche.2020.07.065 
19. Holkar CR, Jadhav AJ, Pinjari DV, Mahamuni NM, Pandit AB (2016) critical review on textile wastewater treatments: Possible approaches. Journal of Environmental Management 182:351-366. https://doi.org/10.1016/j.jenvman.2016.07.090

20. Kabdasli I, Gurel M, Tunay O (2010) Characterization and treatment of textile printing wastewaters. Journal Environmental Technology 21:1147-1155.

https://doi.org/10.1080/09593330.2000.9619001

21. Khandegar V, Saroha AK (2013) Electrocoagulation for the treatment of textile industry effluent - A Review. Journal of Environmental Management 128:949-963. https://doi.org/10.1016/j.jenvman.2013.06.043

22. Lee SY, Gagnon GA (2014) Review of the factors relevant to the design and operation of an electrocoagulation system for wastewater treatment. Environmental Reviews 22:421-429. https://doi.org/10.1139/er-2014-0009

23. Liu S, Li B, Qi P, Yu W, Zhao J, Liu Y (2019) Performance of Freshly Generated Magnesium Hydroxide (FGMH) for Reactive Dye Removal. Colloid and Interface Science Communications 28:34-40. https://doi.org/10.1016/j.colcom.2018.11.004

24. Matias MS, Melegari SP, Vicentini DS, Matias WG, Ricordel C, Hauchard D (2015) Synthetic wastewaters treatment by electrocoagulation to remove silver nanoparticles produced by different routes. Journal of Environmental Management 159;147-157.

https://doi.org/10.1016/j.jenvman.2015.05.006

25. Mollah MYA, Morkovsky P, Gomes JAG, Kesmez M, Parga J, Cocke DL (2004) Fundamentals, present and future perspectives of electrocoagulation. Journal of Hazardous Materials 114:199-210. https://doi.org/10.1016/j.jhazmat.2004.08.009

26. Mook WT, Aroua MK, Szlachta M, Lee CS (2017) Optimisation of Reactive Black 5 dye removal by electrocoagulation process using response surface methodology. Water Science \& Technology 75:952-962. https://doi.org/10.2166/wst.2016.563

27. Nariyan E, Sillanpaa M, Wolkersdorfer C (2017) Electrocoagulation treatment of mine water from the deepest working European metal mine-Performance, isotherm and kinetic studies. Sep. Purif. Technol 177:363-373. https://doi.org/10.1016/j.seppur.2016.12.042

28. Núñez J, Yeber M, Cistemas N, Thibault R, Medina P, Carrasco C (2019) Application of electrocoagulation for the efficient pollutants removal to reuse the treated wastewater in the dyeing process of the textile industry. Journal of hazardous materials 371:705-711. https://doi.org/10.1016/j.jhazmat.2019.03.030

29. Paschoal FMM, Trenuukuisi-Filho G (2005) Aplicação da tecnologia de eletrofloculação na recuperação do corante índigo blue a partir de efluentes industriais. Quím. Nova 28(5):766-772. http://dx.doi.org/10.1590/S0100-40422005000500006

30. Ramazan K, Can OT, Aygun A, Tek A (2019) Comparison of the effects of various supporting electrolytes on the treatment of a dye solution by electrocoagulation process. Colloid and Interface Science Communications 33:100210. https://doi.org/10.1016/j.colcom.2019.100210 
31. Silva L F da, Barbosa A D, Paula H M de, Romualdo L L, Andrade L S. Treatment of paint manufacturing wastewater by coagulation/electrochemical methods: Proposals for disposal and/or reuse of treated water. Water Research 101: 467-475. https://doi.org/10.1016/j.watres.2016.05.006

32. Sirma B, Ozlem B, Burcu P, Gulen T, Suheyda A, Gulin E (2019) Electrocoagulation process for the treatment of real textile wastewater: effect of operative conditions on the organic carbon removal and kinetic study. Process safety and environmental protection 129:47-54. https://doi.org/10.1016/j.psep.2019.06.010

33. Verma AK (2017) Treatment of textile wastewaters by electrocoagulation employing Fe-Al composite electrode. Journal of Water Process Engineering 20:168-172. https://doi.org/10.1016/j.jwpe.2017.11.001

34. Volkov VV, Chelli R, Righini R, Perry CC (2020) Indigo chromophores and pigments: Structure and dynamics. Dyes and Pigments 172:107761. https://doi.org/10.1016/j.dyepig.2019.107761

35. Wang CT, Chou WL, Kuo YM (2009) Removal of COD from laundry wastewater by electrocoagulation. Journal of Hazardous Materials 164:81-89. https://doi.org/10.1016/j.jhazmat.2008.07.122

36. Yin C, Tan X, Bie B, Ma H, Yi H (2020) Practical and environment-friendly indirect electrochemical reduction of indigo and dyeing. Scientific Reports 10:4927. https://doig.org/10.1038/s41598-020$61795-5$

37. Zaroual Z, Azzi M, Saib N, Chainet E (2006) Contribution to the study of electrocoagulation mechanism in basic textile effluent. Journal of Hazardous Materials 131:73-78 https://doi.org/10.1016/j.jhazmat.2005.09.021

38. Zazou H, Afanga H, Akhouairi S, Ouchtak H, Addi AA (2019) Treatment of textile industry wastewater by electrocoagulation coupled with electrochemical advanced oxidation process. Journal of Water Process Engineering 28:214 - 221. https://doi.org/10.1016/j.jwpe.2019.02.006

39. Zazouli MA, Taghavi M (2012) Phenol removal from aqueous solutions by electrocoagulation technology using iron electrodes: effect of some variables. Journal Water Resource Prot 4:980-983. https://doi.org/10.13140/2.1.1837.6967

40. Zodi S, Potier O, Lapicque J. P (2009) Treatment of the textile wastewaters by electrocoagulation: effect of operating parameters on the sludge settling characteristics. Sep. Purif. Technol 69:29-36. https://doi.org/10.1016/j.seppur.2009.06.028

\section{Figures}




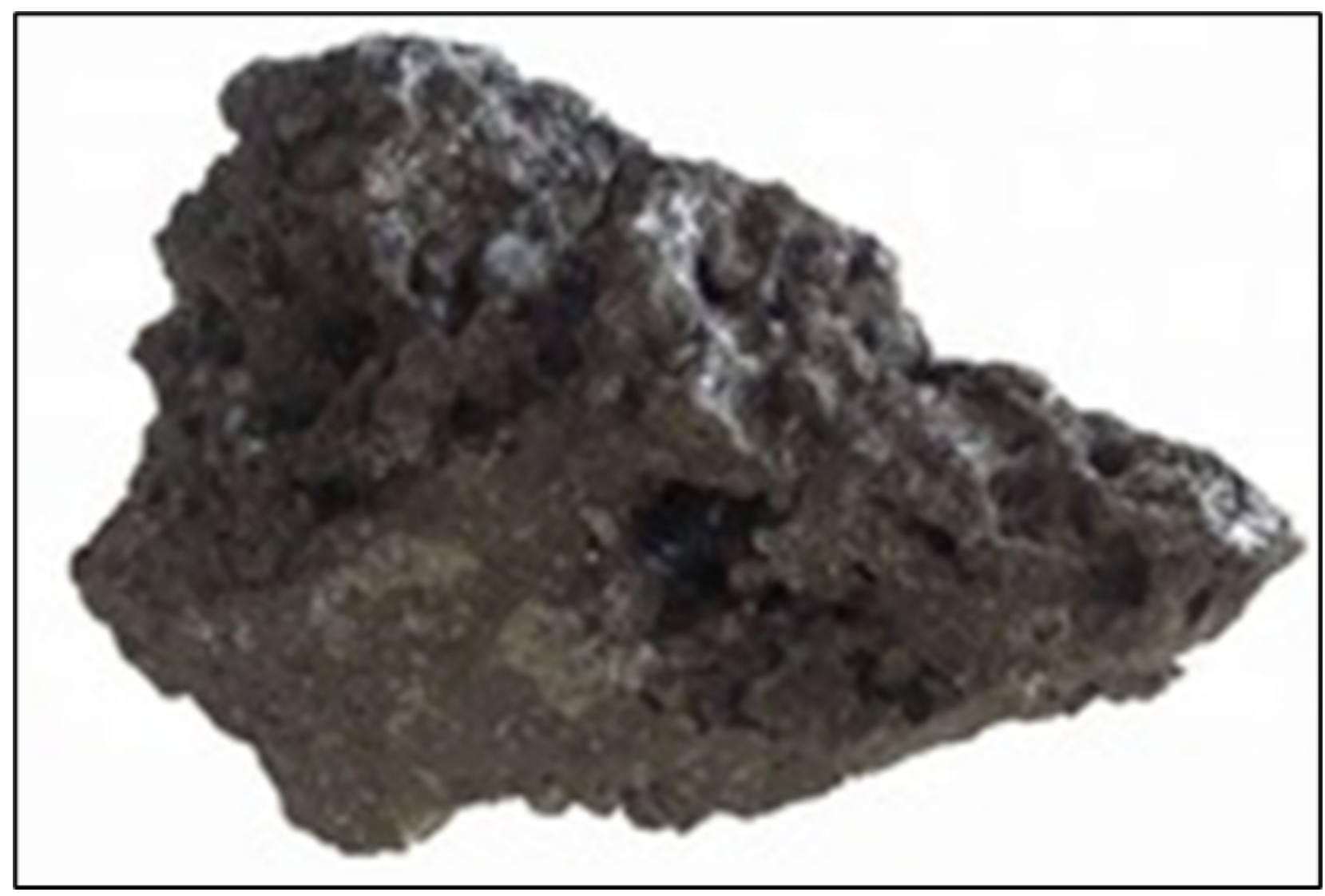

Figure 1

Iron slag used as electrodes for the electrocoagulation system of textile dye and industrial effluent

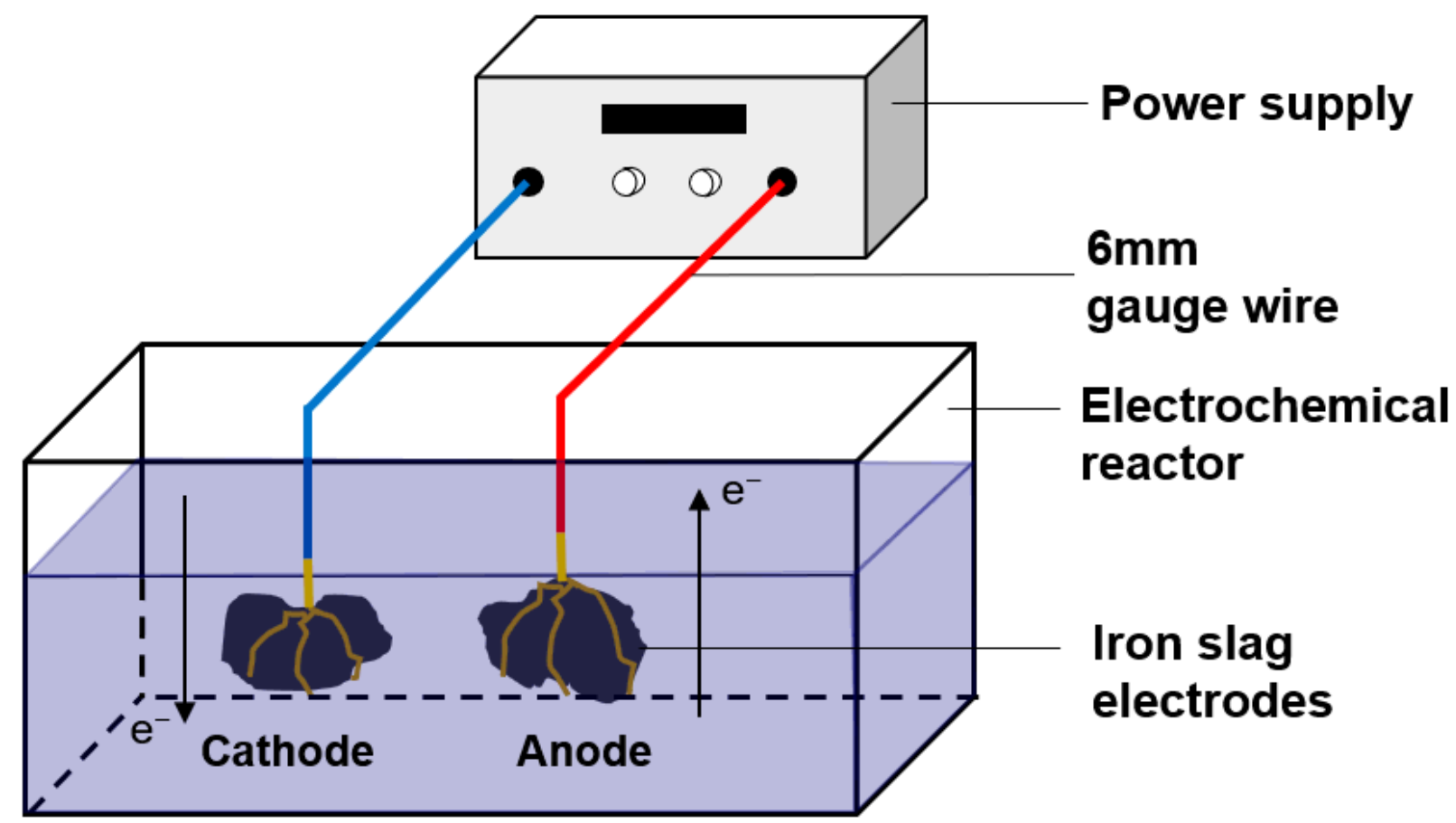


Figure 2

Schematic representation of the electrocoagulation system using iron slag electrodes applied for the oxidation of textile dye in synthetic and industrial effluents

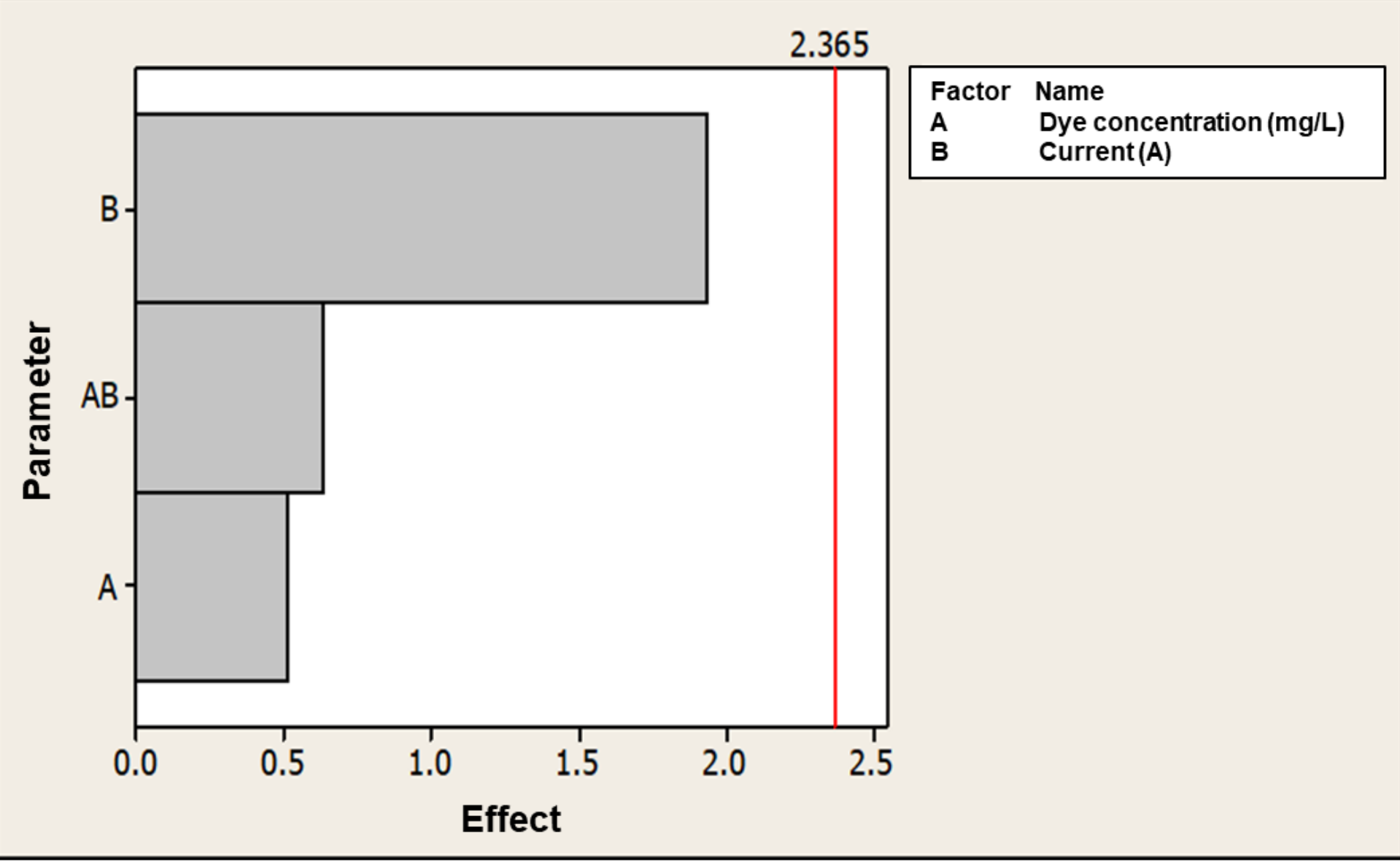

Figure 3

Pareto chart for the analysis of the experimental data obtained for the removal of color from the synthetic textile effluent by the electrocoagulation process using iron slag electrodes with $95 \%$ confidence.
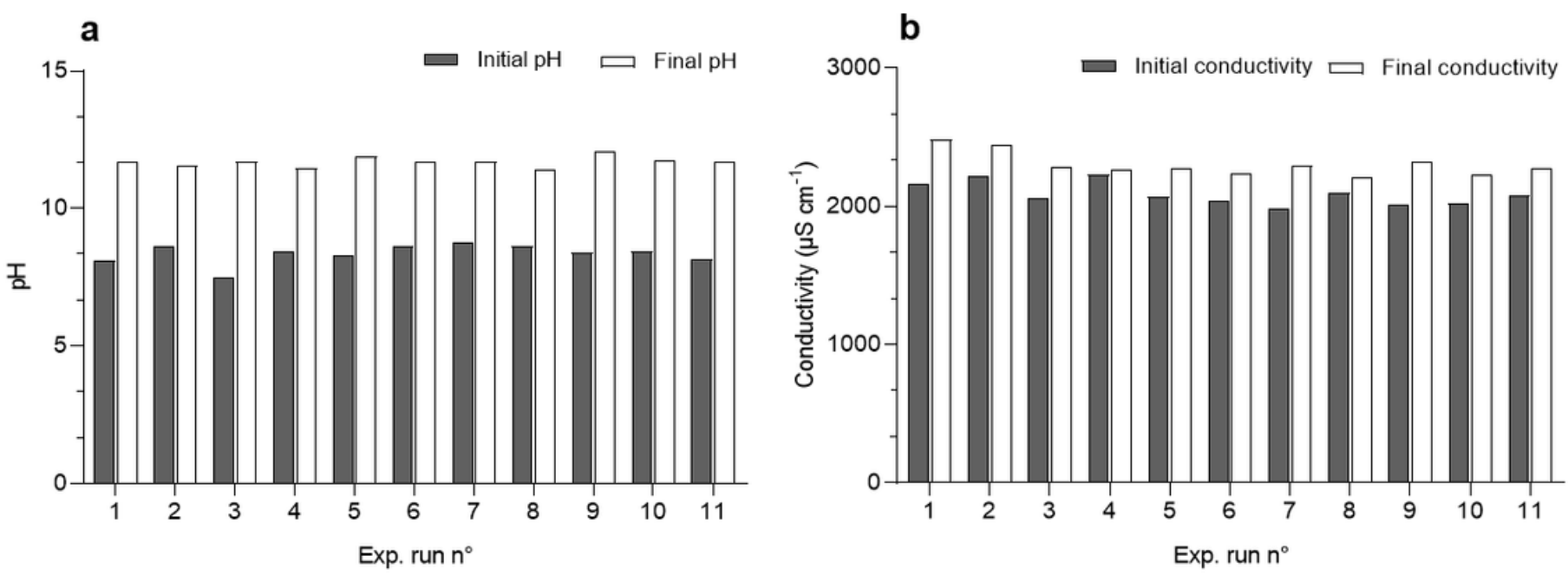
Figure 4

Initial and final $\mathrm{pH}$ (a) and electrical conductivity (b) during the electrocoagulation process for the oxidation of textile dye in a synthetic effluent using iron slag electrodes.

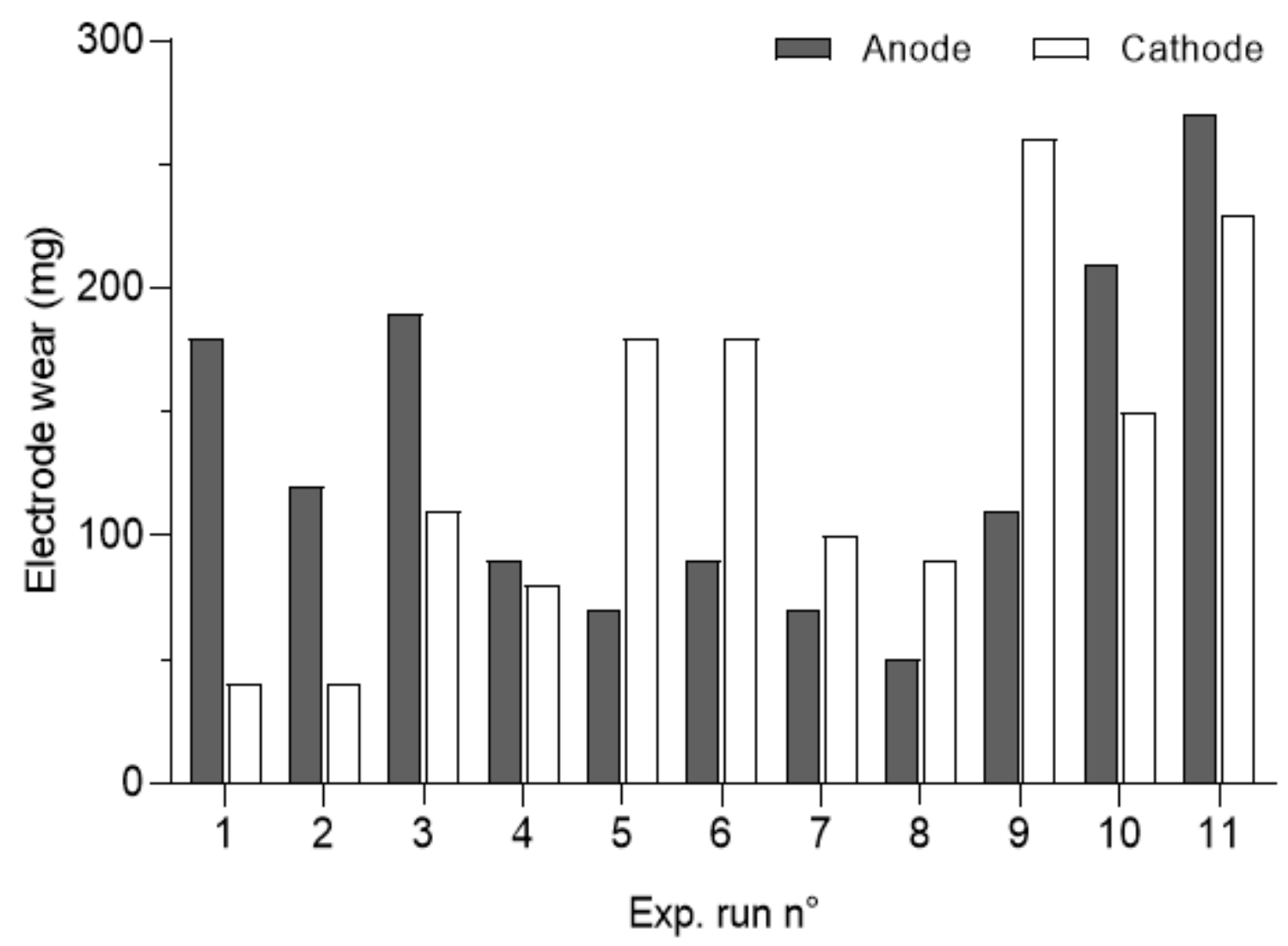

Figure 5

Wear of iron slag electrodes in the electrocoagulation process for the oxidation of textile dye in a synthetic effluent. 


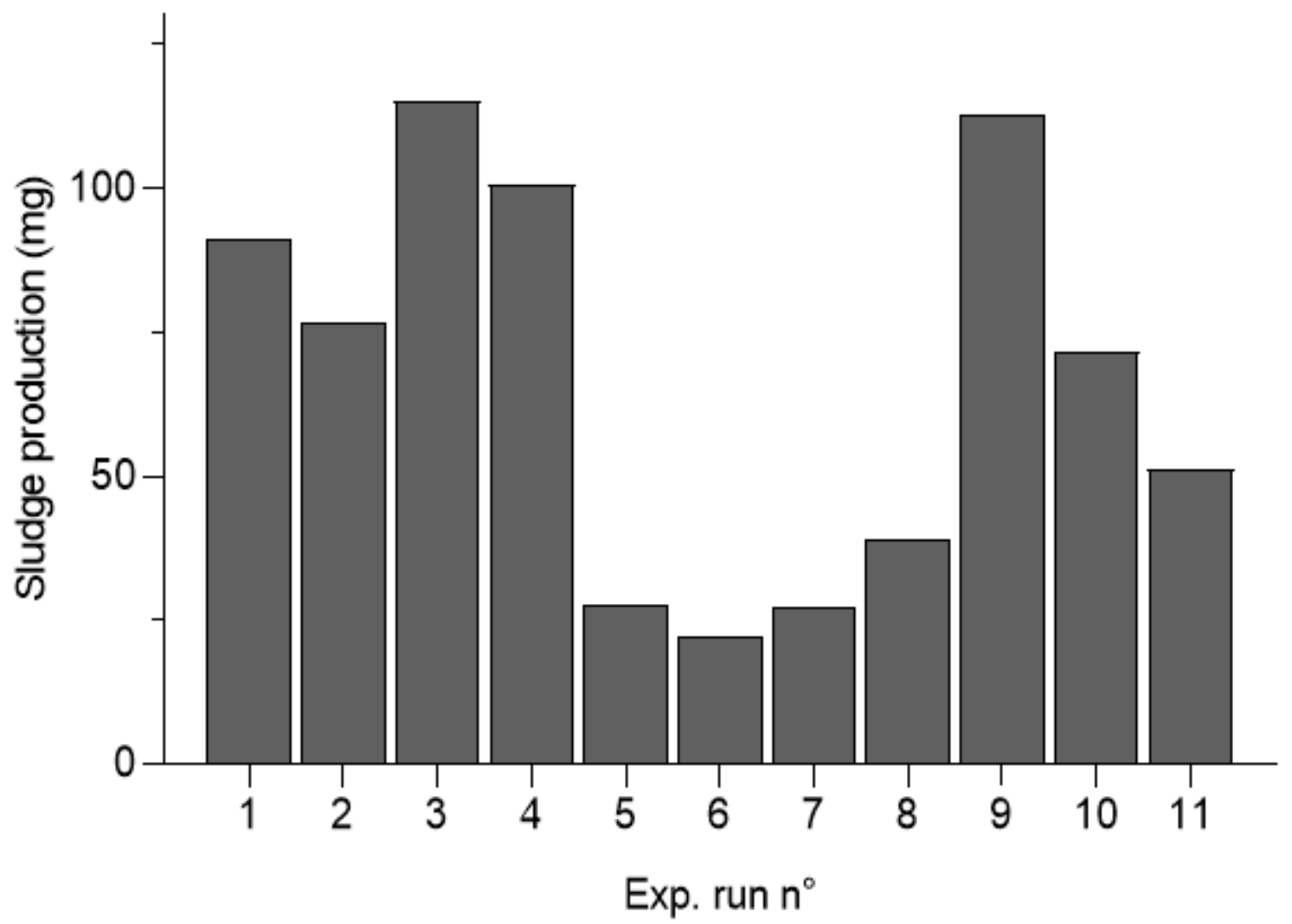

Figure 6

Sludge production by the electrocoagulation process for the oxidation of textile dye in a synthetic effluent using iron slag electrodes. 


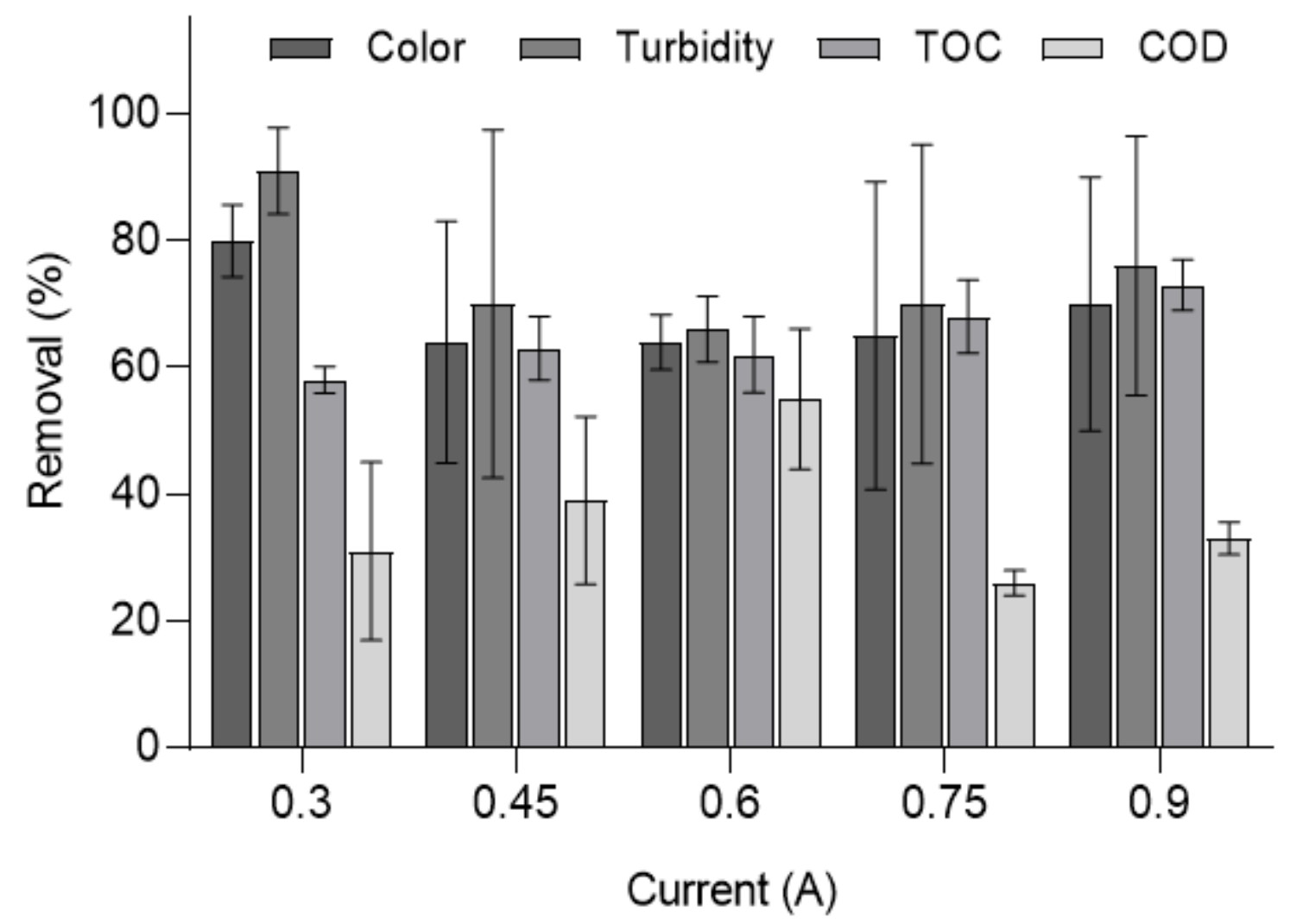

Figure 7

Removal color, turbidity, TOC, and COD by the electrocoagulation process of an industrial textile dye using iron slag electrodes. 


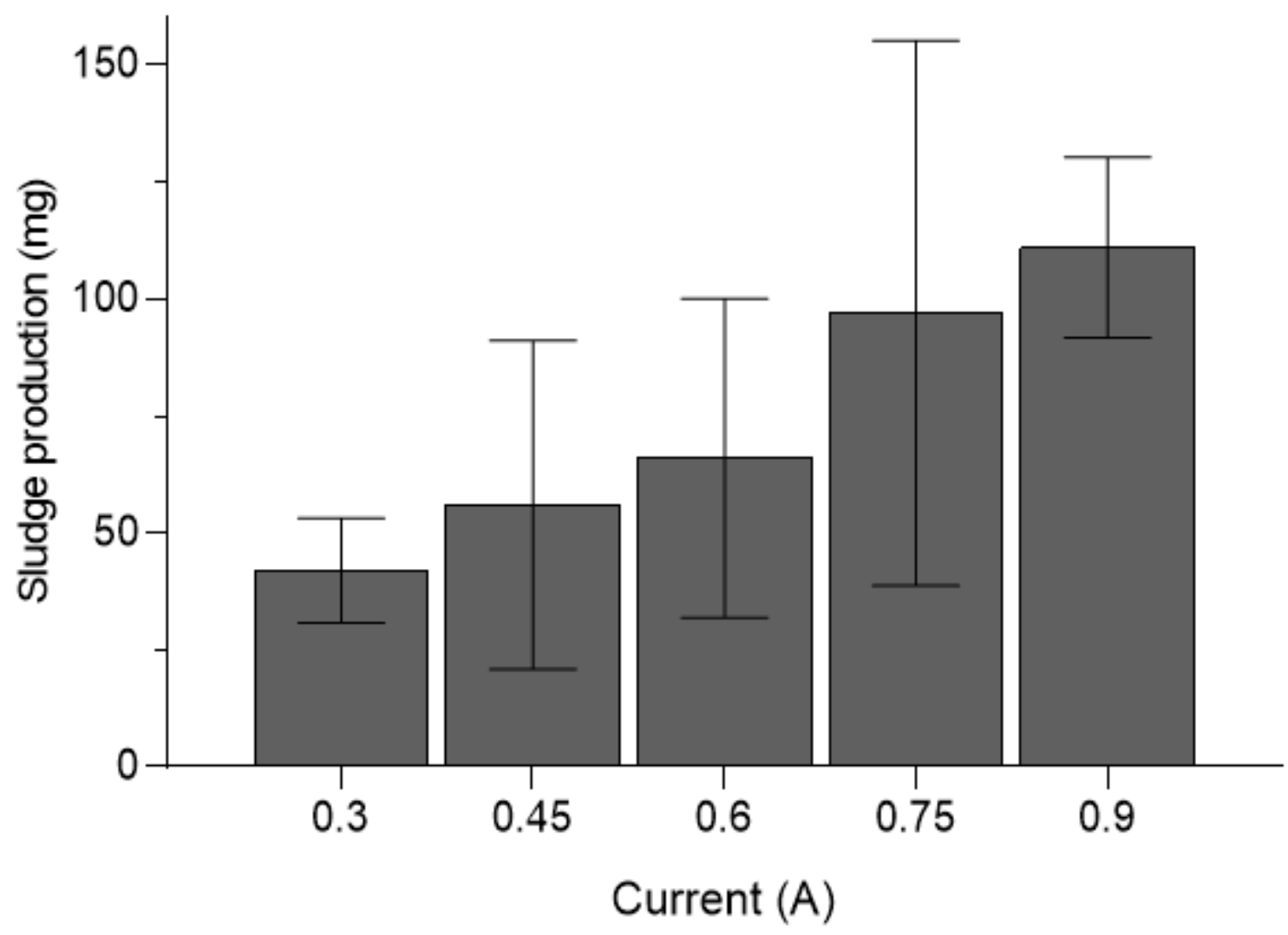

Figure 8

Sludge production by the electrocoagulation process for the oxidation of textile dye in a real effluent using iron slag electrodes.

\section{Supplementary Files}

This is a list of supplementary files associated with this preprint. Click to download.

- ElectronicSupplementaryMaterialEscoria.docx 